\begin{tabular}{l|c|c}
\hline ISSN: 0001-5113 & ACTA ADRIAT., & ORIGINAL SCIENTIFIC PAPER \\
AADRAY & $60(2): 147-156,2019$ & \\
\hline
\end{tabular}

\title{
Northern extension of Lesueurigobius friesii (Malm, 1874) (Pisces: Gobiidae) distribution and the gobiid diversity decline along the Norwegian coast
}

\author{
Marcelo KOVAČIĆ ${ }^{1, *}$ and Rudolf SVENSEN ${ }^{2}$ \\ ${ }^{1}$ Natural History Museum Rijeka, Lorenzov prolaz 1, HR-51000 Rijeka, Croatia \\ ${ }^{2}$ Hundvaag, Norway
}

*Corresponding author:marcelo@prirodoslovni.com

\begin{abstract}
Lesueurigobius friesii was collected in Eidsfjorden, Sognefjorden, Norway, extending its known distribution range north as the new northernmost locality of this species. Globally, the northernmost presence of gobies is along the coast of Norway. Their diversity along the Norwegian coast showed an evident latitude gradient of gobiid diversity with a clear decrease from south to north. The significant regression structural change was found at the $63 / 64^{\circ} \mathrm{N}$ latitude band followed by a $36.4 \%$ decrease in gobiid species diversity. The species traits of gobiids north of the regression breaking point and those restricted to the south of it were compared. The only significantly more frequent characteristic of species passing north of the regression breaking point is the large depth range that reach down to the shelf break. All species present north of the point, except Thorogobius ephippiatus (that barely passes it) belong to Oxudercinae (1.e. to Pomatoschistus lineage of that subfamily).
\end{abstract}

Key words: Gobiidae, geographic distribution, Norway, species diversity

\section{INTRODUCTION}

The family Gobiidae, with 1908 presently valid species is the largest fish family and contains the largest number of new species descriptions in the last ten years (FRICKE et al., 2019). Gobies are also the only species rich fish family present in both marine and freshwater environments, while three other fish families with more than one thousand valid species are exclusively freshwater fishes. However, the majority of marine gobiid species is restricted to shallow water and to warm temperate or tropical seas where the family Gobiidae is often the most species rich family in the area, e.g. in the Red Sea (GOLANI \& BOGORODSKY, 2010) or in the Mediterranean Sea (KOVAČIĆ \& PATZNER, 2011). The small number of gobiid species worldwide are present at depths below the shelf break (KOVAČIĆ et al., 2018), and gobiid diversity also heavily decreases in the cold temperate seas (KOVAČIĆ \& SVENSEN, 2018). The northernmost presence of gobies is along the coast of Norway where representatives of this fish family enter the Arctic Circle (BYRKJEDAL et al., 2016). In the rest of the world, only a few species extend north or south of latitudes greater than $50^{\circ}$, with Rhinogobiops nicholsii (Bean 1882), in the 
North Pacific, reaching the highest latitude (57 17 '26" N) among them (CSEPP \& WING, 2000).

Latitudinal declines of species richness from the tropics to the poles represent a well-known spatial pattern of diversity of living organisms in marine biota (HILLEBRAND, 2004). This latitude gradient of diversity has been confirmed for Eastern Atlantic fish in general (MACPHERSON \& DUARTE 1994), however, no analysis has been done for any individual fish taxa on a regional or local level along the Western European coast.

Lesueurigobius friesii (Malm, 1874) is an Eastern Atlantic and Mediterranean gobiid species present in the Atlantic from Mauritania to Norway (MILLER, 1986). The northernmost published distribution of this species was at Litla Døvika, Strand, Norway (BYRKJEDAL et al., 2002).

The aim of the present study is to report the northernmost extension of the known distribution range of $L$. friesii and to analyze gobiid species diversity by latitude at their northernmost distribution.

\section{MATERIAL AND METHODS}

A single specimen of $L$. friesii was collected by R. Svensen using handnet during SCUBA diving in Eidsfjorden, Sognefjorden, Norway on 24 July 2018. The collected specimen was killed after SCUBA dives by over-anaesthetization with Quinaldine. The material is deposited in the Prirodoslovni muzej Rijeka (PMR VP4366). The morphological diagnosis is a minimum combination of characters that positively identifies fresh or preserved specimens of $L$. friesii among species of the family Gobiidae in the CLOFNAM area (MILLER, 1986; KOVAČIĆ \& PATZNER, 2011; KOVAČIĆ et al., 2018 and references therein). Terminology of the lateral-line system follows MILLER (1986).

The database on the latitudinal distribution of Norwegian gobiid species was compiled from the comprehensive search of the primary literature (Table 1). For the northernmost range of distribution, only the coordinates or exact geographic locality cited in the text were used and no estimation was extracted from published minimaps (e.g. MILLER, 1986; PETHON, 2005). For geographic locality without provided coordinates, the northernmost point of the recorded locality was used for coordinates. The latitudinal pattern of species richness was examined by counting all gobiid species present within one degree latitudinal bands from $58 / 59^{\circ} \mathrm{N}$ to $71 / 72^{\circ}$

Table 1. Distribution of gobies in Norway

\begin{tabular}{|c|c|c|c|}
\hline Species & Distribution in Norway & $\begin{array}{l}\text { The latitude } \\
\text { of the } \\
\text { northernmost } \\
\text { distribution }\end{array}$ & Reference \\
\hline Aphia minuta (Risso, 1810) & Skagerrak to Trondheim & $63^{\circ} 26^{\prime} \mathrm{N}$ & Miller, 1986 \\
\hline Buenia jeffreysii (Günther 1867) & Skagerrak to Trondheim, also Lofoten & $67^{\circ} 30^{\prime} \mathrm{N}$ & Byrkjedale et al., 2016 \\
\hline Crystallogobius linearis (Von Düben, 1845) & Skagerrak to Lofoten & $68^{\circ} 28^{\prime} \mathrm{N}$ & Miller, 1986; Pethon, 2005 \\
\hline Gobius niger Linnaeus, 1758 & Skagerrak to Trondheim & $63^{\circ} 26^{\prime} \mathrm{N}$ & Nash, 1984 \\
\hline Gobiusculus flavescens (Fabricius 1779) & Skagerrak to Vesterålen & $69^{\circ} 19^{\prime} \mathrm{N}$ & Miller, 1986 \\
\hline Lebetus scorpioides (Collett 1874) & $\begin{array}{l}\text { Stavanger to Trondheim, also Lofoten } \\
\text { and Lopphavet }\end{array}$ & $70^{\circ} 34^{\prime} \mathrm{N}$ & Byrkjedale et al., 2016 \\
\hline Lesueurigobius friesii (Malm, 1874) & Skagerrak to Sognefjorden & $61^{\circ} 12^{\prime} 5.9^{\prime} \mathrm{N}$ & present research \\
\hline Pomatoschistus microps (Krøyer 1838) & Skagerrak to Trondheimsfjorden & $63^{\circ} 51^{\prime} \mathrm{N}$ & Miller, 1986 \\
\hline Pomatoschistus minutus (Pallas, 1770) & Skagerrak to Tromsø & $69^{\circ} 39^{\prime} \mathrm{N}$ & Miller, 1986 \\
\hline Pomatoschistus norvegicus (Collett, 1903) & Skagerrak to Lofoten & $68^{\circ} 28^{\prime} \mathrm{N}$ & Webb \& Miller, 1975 \\
\hline Pomatoschistus pictus (Malm, 1865) & Skagerrak to Trondheimsfjorden & $63^{\circ} 51^{\prime} \mathrm{N}$ & Miller, 1986 \\
\hline Thorogobius ephippiatus (Lowe, 1839) & Stavanger to Løgnin fjorden & $64^{\circ} 22^{\prime} 24^{\prime \prime} \mathrm{N}$ & Kovačić \& Svensen, 2018 \\
\hline
\end{tabular}


N. The latitudinal gradient of species richness was assessed through a regression analysis of the number of species versus latitude. The test for structural changes in the linear regression model was based on the $F$ statistics extension of the Chow test to all potential change points (ZEILES et al., 2002). The analysis tests the hypothesis that regression coefficients remain constant against the alternative that at least one coefficient varies over a series using a series of $\mathrm{F}$ statistics for all potential change points in an interval and rejecting the null hypothesis if any of those statistics get too large. The supFstatistic (F) with estimated p-value is calculated for the null hypothesis of no structural change. The breakpoint of the single-shift alternative will be identified if the structural change in the regression relationship is confirmed (ZEILES et al., 2003). The species traits between gobiid species reaching north of the established regression breaking point and those staying restricted to the south of it were compared and differences were tested. The small sample size limits the available statistical methods (MORGAN, 2017). Significance was tested using Fisher's exact test (MCDONALD, 2014) as the significance of differences in frequencies of a particular trait between species present north of the breaking point and species restricted to the south of it. A 5\% level of significance was selected for the evaluation of the tests.

The regression analysis, the test for structural changes in linear regression relationships, and Fisher's exact test were performed in R software version 3.3.3 using RStudio 1.0.143 integrated development environment (IDE) for $\mathrm{R}$ and the Strucchange package, version 1.5-1.

\section{RESULTS}

\section{L. friesii distribution}

Material collected (standard length + caudal fin length): single male, $56.8+17.0 \mathrm{~mm}$, PMR VP4366, Eidsfjorden, south-east of the town Sogndal in Sognefjorden, Norway $\left(61^{\circ} 12^{\prime} 5.9^{\prime \prime}\right.$ N, 7¹0'6.6” E), 24th July 2018, collector R. Svensen (Fig. 1a). Species diagnosis: (1) sub-

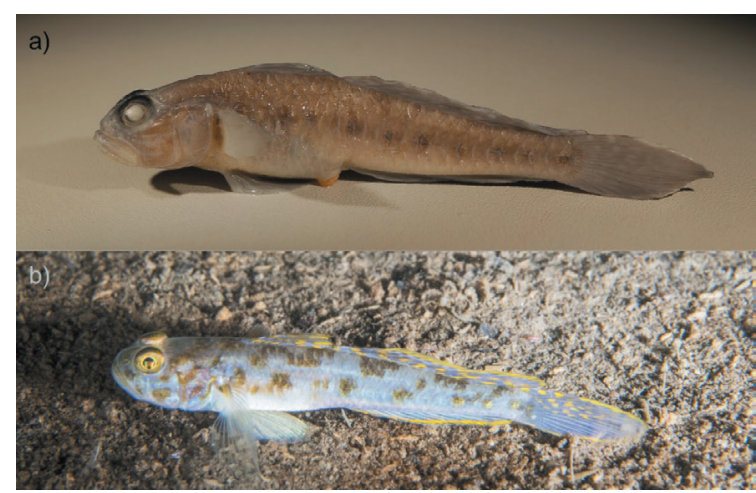

Fig. 1. Lesueurigobius friesii: a) single male, $56.8+17.0$ mm, PMR VP4366, b) one of observed additional specimens, both at Eidsfjorden, south-east of the town Sogndal in Sognefjorden, Norway. Photographs by M. Kovačić (a) and R. Svensen (b)

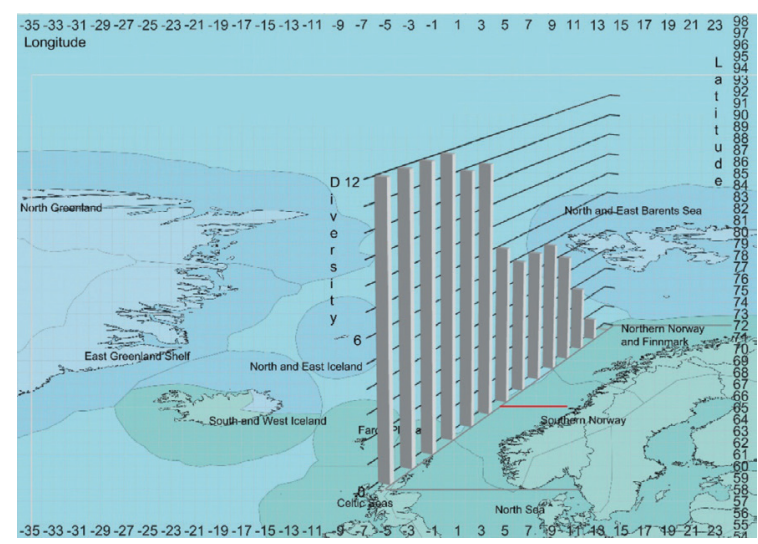

Fig. 2. The gobiid species diversity by latitude for one degree latitudinal bands from $58 / 59^{\circ} \mathrm{N}$ to $71 / 72^{\circ} \mathrm{N}$ along the Norwegian coast. The delimited and labeled marine ecoregions in the area (Spalding et al. 2007). The regression breaking point is indicated by red line after $63 / 64^{\circ} \mathrm{N}$ band. The map was modified from Shorthouse (2010)

orbital papillae of the lateral-line system with longitudinal row $a$; (2) pelvic disc with anterior membrane: (3) head canals absent; (4) suborbital transversal rows absent; (5) nape scaled; (6) pectoral fin with 18-19 rays (present specimen 18). Ecological data: The specimen was collected at $22 \mathrm{~m}$ depth on a muddy sandy bottom. The additional specimens were noticed and photographed (Fig. 1b). Geographical distribution: The present record extends the northernmost species distribution from Litla Døvika, Strand, Rogaland to Eidsfjorden, Sognefjorden (i.e. from $59^{\circ} 07^{\prime} \mathrm{N}$ to $61^{\circ} 12^{\prime} 5.9^{\prime \prime} \mathrm{N}$ ) (Table 1). 
a)

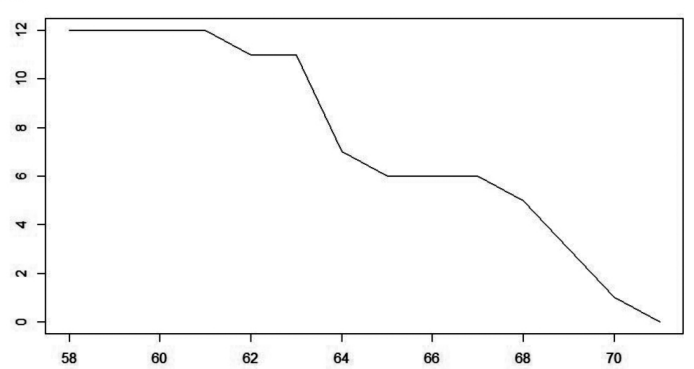

b)

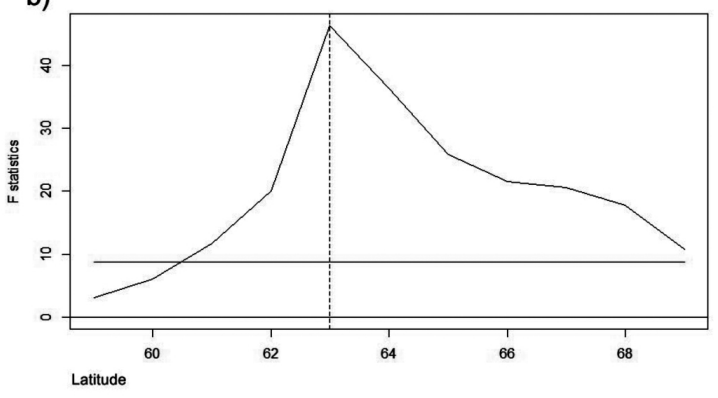

Fig. 3. Test for structural changes: a) original data, b) $F$ statistics, red line corresponds to a supF test at the 5\% significance level, the identified regression breaking point as dotted lin

\section{Latitude distribution and species diversity of gobies along the Norwegian coast}

The diversity of gobies along the Norwegian coast showed a clear decrease from twelve species at the southernmost latitude band $\left(58 / 59^{\circ} \mathrm{N}\right)$ to no gobies present at the northernmost latitude band $\left(71 / 72^{\circ} \mathrm{N}\right)$ (Table 1, Fig. 2). The linear regression model has a highly significant negative regression present and a large portion of the species diversity change is explained by the latitudinal component (intercept $\mathrm{a}=70.94 \pm 5.08$, slope $b=-0.99 \pm 0.08$, coefficient of determination $\mathrm{R}^{2}=0.93$, $\mathrm{F}$-statistic $\mathrm{F}=156.8$, probability $\mathrm{p}<0.001)$. The breakpoint analysis identified the $63 / 64^{\circ} \mathrm{N}$ band as the significant regression structural change point. The decrease in species diversity between $63 / 64^{\circ} \mathrm{N}$ and the next band is $36.4 \%(\mathrm{~F}=46.344$, probability $\mathrm{p}<0.001)$ (Fig. 3 ).

\section{The traits of gobiid species reaching north of the regression breaking point}

The species traits of gobiids reaching north of the regression breaking point and those restricted to south of it are presented and compared in Table 2. The high difference in presence of some species traits were observed between species reaching north of the point of the abrupt species diversity change and those restricted to the south: gobiid species reaching north of the point almost all belong to Oxudercinae (vs. mostly Gobiinae gobies among species restricted to the south of it); with their lower depth limit, almost all of them are able to reach the shelf break (vs. none being able to reach the shelf break among species restricted to the south of it); almost all are annual or biannual (vs. more mixed longevity composition); and they are mostly very small in size, i.e. less than $60 \mathrm{~mm}$, (vs. only one species being very small among those restricted to the south of it) (Table 3). The frequencies of traits were tested for significant differences. Despite differences in frequencies of these traits between gobiid species reaching north of the regression breaking point and those restricted to the south, the significantly different frequency by Fisher's exact test was observed only for the species lower depth limit (Table 3).

\section{DISCUSSION}

The gobiid diversity along the Norwegian coast showed an evident decrease in diversity from south to north with a single strong decrease of $36.4 \%$ at one particular part (i.e. between $63 / 64^{\circ}$ and $64 / 65^{\circ} \mathrm{N}$ latitude bands). The northward decrease could be expected from the known latitudinal declines of species richness for living organisms or just for fishes over broad latitudinal ranges (MACPHERSON \& DUARTE, 1994; HILLEBRAND, 2004). However, the research covering the restricted area with a similar latitudinal range as the present research (56$71^{\circ} \mathrm{N}$ ) showed no evidence of a latitudinal cline in alpha, beta or gamma diversity of macrobenthos along the Norwegian coast (ELLUNGSEN \& GREY, 2002). No similar single breaking point of species diversity decrease along the Norwegian coast was recorded for any other animal taxa like the presently observed decrease for gobies between $63 / 64^{\circ}$ and $64 / 65^{\circ} \mathrm{N}$ latitude bands. The point of the abrupt gobiid species diversity 
Table 2. The species traits of gobiid species. The species restricted to south above mid-table line, those reaching north of the regression breaking point below mid-table line. Data from Gibson \& Ezzi, 1981; Fabi \& Giannetti, 1985; Miller, 1986; Moreira et al., 1991; Arruda et al., 1993; Iglesias \& Morales-Nin, 2001; Ahnelt \& Dorda, 2004; Beldade et al., 2006; Kovačić \& La Mesa, 2010; Herler et al., 2014; Stern et al., 2018. The longevity of B. jeffreysii was estimated from age of sister species B. affinis Iljin, 1930

\begin{tabular}{|c|c|c|c|c|c|c|}
\hline Species & Taxonomy & $\begin{array}{l}\text { Depth } \\
\text { range } \\
(\mathrm{m})\end{array}$ & $\begin{array}{l}\text { Geographic } \\
\text { distribution }\end{array}$ & Bottom preferences & $\begin{array}{l}\text { Longevity } \\
\text { (y) }\end{array}$ & $\begin{array}{l}\text { Maximum } \\
\text { size }(\mathrm{mm})\end{array}$ \\
\hline A. minuta & Gobiinae & $5-90$ & $\begin{array}{l}\text { cold and warm } \\
\text { temperate sea }\end{array}$ & nectonic & 1 & 79 \\
\hline G. niger & Gobiinae & $1-96$ & $\begin{array}{l}\text { cold and warm } \\
\text { temperate sea }\end{array}$ & $\begin{array}{l}\text { epibenthic various } \\
\text { bottom }\end{array}$ & 5 & 150 \\
\hline L. friesii & Gobiinae & $10-130$ & $\begin{array}{l}\text { cold and warm } \\
\text { temperate sea }\end{array}$ & $\begin{array}{l}\text { epibenthic soft } \\
\text { sediment }\end{array}$ & 11 & 130 \\
\hline P. microps & Oxudercinae & $0-12$ & $\begin{array}{l}\text { cold and warm } \\
\text { temperate sea }\end{array}$ & $\begin{array}{l}\text { epibenthic soft } \\
\text { sediment }\end{array}$ & 2 & 64 \\
\hline P. pictus & Oxudercinae & $1-55$ & $\begin{array}{l}\text { cold and warm } \\
\text { temperate sea }\end{array}$ & $\begin{array}{l}\text { epibenthic soft } \\
\text { sediment }\end{array}$ & $<3$ & 57 \\
\hline B. jeffreysii & Oxudercinae & $5-330$ & cold temperate sea & $\begin{array}{l}\text { epibenthic various } \\
\text { bottom }\end{array}$ & 1 & 60 \\
\hline C. linearis & Oxudercinae & $1-400$ & $\begin{array}{l}\text { cold and warm } \\
\text { temperate sea }\end{array}$ & nectonic & 1 & 47 \\
\hline G. flavescens & Oxudercinae & $0-20$ & $\begin{array}{l}\text { cold and warm } \\
\text { temperate sea }\end{array}$ & hyperbenthic & 2 & 60 \\
\hline L. scorpioides & Oxudercinae & $30-375$ & cold temperate sea & $\begin{array}{l}\text { epibenthic various } \\
\text { bottom }\end{array}$ & 2 & 39 \\
\hline P. minutus & Oxudercinae & $2-200$ & $\begin{array}{l}\text { cold and warm } \\
\text { temperate sea }\end{array}$ & $\begin{array}{l}\text { epibenthic soft } \\
\text { sediment }\end{array}$ & $<3$ & 95 \\
\hline P. norvegicus & Oxudercinae & $18-325$ & $\begin{array}{l}\text { cold and warm } \\
\text { temperate sea }\end{array}$ & $\begin{array}{l}\text { epibenthic soft } \\
\text { sediment }\end{array}$ & $<3$ & 72 \\
\hline T. ephippiatus & Gobiinae & $6-40$ & $\begin{array}{l}\text { cold and warm } \\
\text { temperate sea }\end{array}$ & $\begin{array}{l}\text { epibenthic hard and } \\
\text { mixed bottom }\end{array}$ & 9 & 130 \\
\hline
\end{tabular}

Table 3. The frequencies of species traits between species present north of the regression breaking point and species restricted south of it and the results of Fisher's exact test on these frequencies $(*$ indicates significant p-values $<0.05)$

\begin{tabular}{|c|c|c|c|c|c|c|c|c|c|}
\hline & Taxonomy & & Lower depth lin & & Lifespan & & Size & & \\
\hline & Oxudercinae & Gobiinae & $\begin{array}{l}\text { Reaching shelf } \\
\text { break }\end{array}$ & $\begin{array}{l}\text { Not } \\
\text { reachin } \\
\text { shelf } \\
\text { break }\end{array}$ & $\begin{array}{l}\text { g Annual or } \\
\text { biannual } \\
\text { species }\end{array}$ & $\begin{array}{l}\text { Multiannual } \\
\text { species }\end{array}$ & $\begin{array}{l}\text { Less than } \\
60 \mathrm{~mm}\end{array}$ & \multicolumn{2}{|l|}{$\begin{array}{l}\text { More } \\
\text { than } 60 \\
\mathrm{~mm}\end{array}$} \\
\hline $\begin{array}{l}\text { Restricted south } \\
\text { of the point }\end{array}$ & & 2 & 3 & 0 & 5 & 3 & 2 & 1 & 4 \\
\hline $\begin{array}{l}\text { Reaching north } \\
\text { of the point }\end{array}$ & & 6 & 1 & 6 & 1 & 6 & 1 & 4 & 3 \\
\hline $\begin{array}{l}\text { Fisher's exact } \\
\text { test (p-value) }\end{array}$ & & 0.2222 & $0.01515^{*}$ & & 0.5227 & & 0.2929 & & \\
\hline
\end{tabular}


change also shows no match with boundaries of known marine ecoregions, since it is nested deep inside the Southern Norway ecoregion, distant from its boundary to Northern Norway and Finnmark (Fig. 2). It also shows no match with the boundaries of large marine ecosystems, being nested deep inside the Norwegian Shelf Large Marine Ecosystem (LME) (SPALDING et al., 2007; SHERMAN \& HEMPEL, 2009).

The evident northward decrease of gobiid species diversity is hard to question from the presented data as the real gobiid species distribution in nature. However, the strong decrease at $64^{\circ} \mathrm{N}$ latitude as the real pattern in nature can be questioned and consequently tested in the future by researches north of the regression breaking point. It can be challenged by two alternative "lack of research" hypotheses: that there is no point in the abrupt species diversity change at all (i.e. the uniform decrease of gobiid diversity exists from that point toward the north), or that the abrupt diversity decrease point is placed farther north than what has been discovered now. Both alternative hypotheses presume that species recorded just south of the $64^{\circ}$ $\mathrm{N}$ latitude are present but not yet recorded north of it. The researches of Norwegian gobies have not been intensive, with only a few recently published ichthyological papers focused exclusively on diversity and biogeography of this taxon (BYRKJEDAL et al., 2002; 2016; KOVAČIĆ \& SVENSEN, 2018). However, the majority of species now restricted to the south are more easily detected and recorded than most of the species able to reach farther north, e.g. Gobius niger Linnaeus, 1758, L. friesii, and Thorogobius ephippiatus (Lowe, 1839) (that barely passes the regression breaking point) are much larger and more intensively colored than "north extended" species, while Pomatoschistus microps (Krøyer, 1838) and Pomatoschistus pictus (Malm, 1865) can be numerous in very shallow water and therefore hard to overlook (Table 2). This is contrary to the expectation that the low research effort, if that is the case to the north, would first recognize easily detected species.

It could be expected that the clear decrease in gobiid species diversity going north at this small scale at high latitudes (i.e. along the Norwegian coast), is related to the general warm temperate to tropical characteristic of this taxon. It is known that among the possible environmental factors that can explain the latitudinal pattern of species richness for benthic fishes and invertebrates, the sea-surface temperature (SST) is the best predictor showing a positive relationship with diversity (MACPHERSON, 2011). However, no pattern of northward decreases in long term winter average SST along the entire Norwegian coast and along the Norwegian Coastal Current (NCC) is visible, and there is no strong temperature decrease south to north of $64^{\circ} \mathrm{N}$ latitude that could match the gobiid species diversity decreasing point (SÆRTRE et al., 2003). On the contrary, the long term winter average SST increases from the most southern stations northwards, being highest, i.e. about $5^{\circ} \mathrm{C}$, both north and south around the point of the strong gobiid species diversity change, finally decreasing again at the Norway northernmost stations (Fig. 2 and Table 2 in SÆRTRE et al., 2003). There is obviously no easy answer which environmental factor or their combination shapes the latitudinal decrease of gobiid species richness and established regression breaking point along the Norwegian coast.

The significant difference in depth range was noticed between species reaching north of the regression breaking point and those restricted to the south of it. All species that are able to reach as deep as the shelf break were able to extend their distribution north of the abrupt species diversity change, and only one species that is restricted to shallow waters, Gobiusculus flavescens (Fabricius, 1779), has managed to extend its distribution north as well (Table 2). It is not clear if the species are able to adapt in the north because the adaptations developed for deep waters help also with survival in the north waters, or deep waters in the north provides some kind of refuge for survival of gobiid populations at these high latitudes in extreme moments. There are a few traits prevailing in species able to reach north of the regression breaking point but failing to be significantly more frequent among them than in the south 
limited species. All of these species traits are more or less shared within a single taxonomic or phylogenetic group (Table 2). All species north of the regression breaking point, except T. ephippiatus (that barely passes it), belong to Oxudercinae, i.e. to the Pomatoschistus lineage of that subfamily (AGORRETA et al., 2013), which is the only branch of Oxudercinae present in European seas and furthermore with distribution also limited only to these seas. Species of the Pomatoschistus lineage are generally annual or biannual species and on the average small sized, contrary to almost all species (except $A$. minuta) of two Gobiinae lineages present in Norwegian waters. Oxudercinae are tropical and temperate sea gobies and mostly inhabit estuaries with some freshwater species (from PEZOLD, 2011), there as Gobionellidae). Contrary to the Pomatoschistus lineage, Oxudercinae in general are not restricted to a short lifespan and small size. It appears that the evolution of the Pomatoschistus lineage has developed the unique potential among Oxudercinae to deal with deep waters and high latitudes, while the latter is also unique among Gobiidae in general. However, presently it is not clear which of the biological or ecological characteristics shared within the taxon help that capability.

\section{ACKNOWLEDGMENTS}

This work has been supported in part by the grant of the Croatian Science Foundation under the project IP-2016-06-9884 and in part by the grant of the Croatian Science Foundation under the project IP-2016-06-5251. We thank Emily Troyer for the English editing and advices.

\section{REFERENCES}

AGORRETA, A., D. SAN MAURO, U. SCHLIEWEN, J.L. VAN TASSELL, M. KOVAČIĆ, R. ZARDOYA \& L. RUBER L. 2013. Molecular phylogenetics of Gobioidei and phylogenetic placement of European gobies. Molecular Phylogenetics and Evolution, 69: 619-633.

AHNELT, H. \& J. DORDA. 2004. Gobioid fishes from the north eastern Atlantic and the

Mediterranean: new records and rarely found species. Annalen des Naturhistorichen Museums in Wien, 105B: 5-19.

ARRUDA, L.M., J.N. AZEVEDO \& A.I. NETO. 1993. Abundance, age-structure and growth and reproduction of gobies (Pisces; Gobiidae) in the Ria de Aveuiro Lagoon (Portugal). Estuarine, Coastal and Shelf Science, 37: 509-523. BELDADE, R., R. BORGES \& E.J. GONÇAVLES. 2006. Depth distribution of nearshore temperate fish larval assemblages near rocky substrates. Journal of Plankton Research 28: 1003-1013. BYRKJEDAL, I., P. PETHON \& R. SVENSEN. 2002. Spisshalekutling Lesueurigobius friesii funnet i Rogaland. Fauna, 55(3): 105-107.

BYRKJEDAL, I., R. WIENERROITHER \& G. JENSEN. 2016. Lebetus scorpioides and Buenia jeffreysii (Teleostei: Gobiidae) found north of the
Arctic Circle. Fauna Norvegica, 36: 47-50.

CSEPP, D.J. \& B.L. WING. 1999. Northern range extensions and habitat observations for blackeye gobies Rhinogobiops nicholsii and Kelp Perch Brachyistius frenatus in southeastern Alaska. Alaska Fishery Research Bulletin, 6(2): 78-84.

ELLINGSEN, K.E. \& J.S. GRAY. 2002. Spatial patterns of benthic diversity: is there a latitudinal gradient along the Norwegian continental shelf? Journal of Animal Ecology, 71: 373389.

FABI, G. \& G. GIANNETTI. 1985. Groth parameters of the black goby (Gobius niger L.) in the Adriatic Sea, based on otolith readings. Rapports Commission Internationale pour l'Exploration Scientifique de la Mer Méditerree, 29: 87-90.

FRICKE, R., W.N. ESCHMEYER \& J.D. FONG. 2019. ESCHMEYER,S CATALOG OF FISHES: SPECIES BY FAMILY/SUBFAMILY. (http:// researcharchive.calacademy.org/research/ ichthyology/catalog/SpeciesByFamily.asp). Electronic version accessed 4 September 2019. 
GIBSON, R.N. \& I.A. EZZI. 1981. The biology of the Norway goby, Pomatoschistus norvegicus (Collett), on the west coast of Scotland. Journal of Fish Biology, 19: 697-714.

GOLANI, D. \& S.V. BOGORODSKY. 2010. The fishes of the Red Sea - Reappraisal and updated checklist. Zootaxa, 2463: 1-135.

HERLER, J, J.T. WILLIAMS \& M. KOVAČIĆ. 2014. Pomatoschistus minutus. The IUCN Red List of Threatened Species 2014: e.T198668A45109442. (http://dx.doi org/1 0.2305/IUCN.UK.2014-3.RLTS. T198668A45109442.en) Electronic version accessed 4 September 2019.

HILLEBRAND, H. 2004. Strength, slope and variability of marine latitudinal gradients. Marine Ecology Progress Series, 273: 251-267.

IGLESIAS, M. \& B. MORALES-NIN. 2001. Life cycle of the pelagic goby Aphia minuta (Pisces. Gobiidae). Scientia Marina, 65: 183-192.

KOVAČIĆ, M. \& M. LA MESA. 2010. First data on reproduction and growth of Buenia affinis Iljin, 1930 in the northern Adriatic Sea. Scientia Marina, 74: 561-568.

KOVAČIĆ, M. \& R.A. PATZNER. 2011. North-Eastern Atlantic and Mediterranean gobies. In: Patzner RA, Van Tassell JL, Kovačić M, Kapoor BG, editors. The biology of gobies. Taylor \& Francis Group, New York, NY: Science Publishers, CRC Press, p 177-206.

KOVAČIĆ, M. \& R. SVENSEN. 2018. The confirmed and continuous northern distribution of Thorogobius ephippiatus (Teleostei: Gobiidae) with the scientific use of recreational fishing data. Journal of Applied Ichthyology, 34: 691-693.

KOVAČIĆ, M., F. ORDINES \& U.K. SCHLIEWEN. 2018. A new species of Buenia (Perciformes: Gobiidae) from the western Mediterranean slope bottoms, the redescription of Buenia jeffreysi and the first Balearic record of Buenia affinis. Zootaxa, 4932 (2): 267-288.

MACPHERSON, E. 2011. Large-scale species-richness gradients in the Atlantic Ocean. Proceedings of the Royal Society of London. Series B, 269: 1715-1720.

MACPHERSON, E. \& C.M. DUARTE. 1994. Patterns in species richness, size, and latitudinal range of East Atlantic fishes. Ecography, 17: 242-248.

MCDONALD, J.H. 2014. Handbook of Biological Statistics ( $3^{\text {rd }}$ Edition). Baltimore, Maryland, Sparky House Publishing, p 305.

MILLER, P.J. 1986. Gobiidae. In: Whitehead PJP, Bauchot M-L, Hureau J-C, Nielsen J, Tortonese $\mathrm{E}$, editors. Fishes of the North-eastern Atlantic and the Mediterranean. Paris: UNESCO, p 1019-1085.

MOREIRA, F., J.L. COSTA, P.R. ALMEIDA, C. ASSIS \& M.J. COSTA. 1991. Age determination in Pomatoschistus minutus (Pallas) and Pomatoschistus microps (Kreyer) (Pisces: Gobiidae) from the upper Tagus estuary, Portugal. Journal of Fish Biology, 39: 433-440.

MORGAN, C.J. 2017. Use of proper statistical techniques for research studies with small samples. American Journal of Physiology - Lung Cellular and Molecular Physiology, 313: 873-877.

NASH, R.D.M. 1984. Aspects of biology of the black goby, Gobius niger L., in Oslofjorden, Norway. Sarsia, 69: 55-61.

PETHON, P. 2005. Aschehougs store fiskebok Norges fisker i farger. Oslo, Norway: Aschehoug, p 468.

PEZOLD, F. 2011. Systematics of Gobionellidae. In: Patzner RA, Van Tassell JL, Kovačić M, Kapoor BG, editors. The biology of gobies. Taylor \& Francis Group, New York, NY: Science Publishers, CRC Press, pp. 87-97.

SÆTRE. R., J. AURE J. \& D.S. DANIELSSEN. 2003. Long-term hydrographic variability patterns off the Norwegian coast and in the Skagerrak. ICES Marine Science Symposia, 219: 150-159.

SHERMAN, K. \& G. HEMPEL. 2009. Perspectives on regional seas and the large marine ecosystem approach. In: Sherman K, Hempel G, editors. The UNEP large marine ecosystem report: a perspective on changing conditions in LMEs of the world's regional seas. UNEP Regional Seas Reports and Studies, 182. Nairobi, Kenya: UNEP, p 3-21

SHORTHOUSE, D.P. 2010. SimpleMappr, an online tool to produce publication-quality point maps. (http://www.simplemappr.net). Accessed 17 December 2018. 
SPALDING, M.D., H.E. FOX, G.R. ALLEN, N. DAVIDSON, Z.A. FERDANA, C. FINLAYSON, B.S. HALPERN, M.A. JORGE, A. LOMBANA, S.A. LOURIE, K.D. MARTIN, E. MCMANUS, J. MOLNAR, C.A. RECCHIA \& J. ROBERTSON. 2007. Marine ecoregions of the world: A bioregionalization of coastal and shelf areas. BioScience, 57(7): 573-583.

STERN, N., A. WEISSMAN \& Y. MAKOVSKY. 2018. East and deep: Range extension and depth record for The leopard-spotted goby Thorogobius ephippiatus (Lowe, 1839) (Osteichthyes: Gobiidae). Journal of Applied Ichthyology, 34: 681-683.
WEBB, C.J. \& P.J. MILLER. 1975. A redescription of Pomatoschistus norvegicus (Collett, 1903) (Teleostei:Gobioidei) based on syntype material. Journal of Fish Biology, 7: 735-747.

ZEILES, A., F. LEISCH, K. HORNIK \& C. KLEIBER. 2002. strucchange: An R Package for Testing for Structural Change in Linear Regression Models. Journal of Statistical Software, 7: 1-17.

ZEILEIS, A. C. KLEIBER, W. KRÄMER \& K. HORNIK. 2003. Testing and dating of structural changes in practice. Comput. Stat. Data. Anal., 44: 109-123.

Received: 5 September 2019

Accepted: 30 October 2019 


\title{
Najsjeverniji nalaz glavoča repaša Lesueurigobius friesii (Malm, 1874) (Pisces: Gobiidae) i smanjivanje raznolikosti glavoča uzduž Norveške obale
}

\author{
Marcelo KOVAC̆IĆ i Rudolf SVENSEN
}

Kontakt e-pošta: marcelo@prirodoslovni.com

\begin{abstract}
SAŽETAK
Glavoč repaš Lesueurigobius friesii sakupljen je u Eidsfjorden, Sognefjorden, Norveška, što predstavlja najsjeverniji nalaz ove vrste. Globalno, najsjevernija rasprostranjenost glavoča nalazi se uz obale Norveške. Raznolikosti vrsta glavoča jasno se smanjuje od juga prema sjeveru uzduž Norveške obale. Statistički značajna strukturna promjena regresije utvrđena je na pojasu 63/64 sjeverne zemljopisne širne popraćena $36.4 \%$ smanjenjem raznolikosti vrsta glavoča. Osobine vrsta glavoča sjeverno od točke loma regresije uspoređene su s osobinama vrsta ograničenim južno od nje. Jedina značajno češća osobina vrste glavoča koje prolaze sjeverno od točke loma regresija je veći raspon dubina, koji kod ovih vrsta seže do ruba kontinentske podine. Također sve vrste sjeverno od točke loma, osim vrste Thorogobius ephippiatus (koja je jedva prolazi), pripadaju potporodici Oxudercinae, točnije Pomatoschistus grupi te potporodice.
\end{abstract}

Ključne riječi: Gobiidae, zemljopisna rasprostranjenost, Norveška, raznolikost vrsta 